\title{
On Sensationalism, Violence and Academic Knowledge
}

Du sensationnalisme, de la violence et de la connaissance scientifique

Sobre sensacionalismo, violencia y conocimiento académico

\section{Hettie Malcomson}

\section{(2) OpenEdition}

\section{Journals}

Electronic version

URL: http://journals.openedition.org/transposition/4931

DOI: 10.4000/transposition.4931

ISSN: 2110-6134

Publisher

CRAL - Centre de recherche sur les arts et le langage

\section{Electronic reference}

Hettie Malcomson, «On Sensationalism, Violence and Academic Knowledge », Transposition [Online], Hors-série 2 | 2020, Online since 15 March 2020, connection on 15 April 2020. URL : http:// journals.openedition.org/transposition/4931 ; DOI : https://doi.org/10.4000/transposition.4931

This text was automatically generated on 15 April 2020

La revue Transposition est mise à disposition selon les termes de la Licence Creative Commons Attribution - Partage dans les Mêmes Conditions 4.0 International. 


\title{
On Sensationalism, Violence and Academic Knowledge
}

\author{
Du sensationnalisme, de la violence et de la connaissance scientifique \\ Sobre sensacionalismo, violencia y conocimiento académico
}

Hettie Malcomson

\section{AUTHOR'S NOTE}

\section{Acknowledgements}

This project was funded by a Leverhulme Research Fellowship grant. I am extremely grateful to the research participants for generously giving me their time and insights. I also wish to thank friends and colleagues who provided really helpful comments and suggestions (you know who you are). All shortcomings are my own.

1 In his reflection on death in the Mexican/US border city of Ciudad Juárez, journalist Charles Bowden wrote about a hypothetical performance by ghosts where voices would be quiet and other sounds, including post-death silence, subdued; a performance where:

We will not allow anyone with answers to be present. Explanations will be killed on sight. Theories strangled by my own hands. No one can speak of cartels if he [sic] is not a member of a cartel [...] Academic commentators must show video of themselves at the killings or having beers with the killers before they will be allowed to say a single word. ${ }^{1}$

Bowden's somewhat macho stance may seem extreme, but I contend that it is a position that must be engaged with seriously. It raises methodological, analytical and representational issues that continue to challenge scholars addressing bellicose violence: Is it ethical to write about terror, pain and despair from afar; to provide answers and explanations; to use theoretical material in such discussions? Can sensationalism ever be justified in analyses of bellicose violence? Are we tuned in enough to notice the distinction between sensational and non-sensational 
representations? What kind of silences might we allow for? In this essay, I address these questions in relation to necropolitical Mexico, drawing from my empirical research with musicians commissioned to write narco rap, producers and consumers of rap del barrio (which is sometimes linked to gangs); and hip hop artists protesting the disappearances, homicides, systematic violence and impunity enjoyed by criminal organisations and state institutions alike.

\section{Lunching with someone who has killed another human}

Whilst researching Mexican popular music, I have lunched with two men who told me that they have killed others. The first was someone I know well, a former security guard I spent many hours dancing with while researching the popular music-dance form, danzón: my curiosity got the better of me when we were eating one day, and I asked him if he had killed anyone. He responded in unemotional, factual terms, describing an event where a man drew a firearm in a dance hall, and he reacted by grabbing the gun and killing the man. This seemed to him like a sensible solution. I was shocked, but the account did not stick to me for long.

The second time I knowingly lunched with someone who had killed people was more difficult. This man was just tagging along with some rappers I was interviewing. While we were eating, it was revealed that he was not only a rap fan, but had been "one of Them" (an ex-narco), and I was encouraged to interview him. ${ }^{2}$ He was delighted to consent, and I was keen to get his perspective on who commissioned narco rap, how, the veracity of the information They gave musicians, and how this genre was consumed. ${ }^{3}$ I set out my interests and let him speak. He told me how he had killed seven people at first hand (not counting those involved in shoot outs); how he was distressed by the sounds that their bodies made as he did so; how hearing the screams of his friends being tortured over the walkie-talkie disturbed him; and how he had made stew out of body parts while tanked up on cocaine. I stopped him, aware that I was not coping with hearing first-hand about the visceral details of such gruesome violence. It continues to unsettle me. ${ }^{4}$ Trust, empathy and power were entangled in our relationship in ways I had not experienced before. Part confessional, part a plea for acceptance as a humane being, but also part assertion of power should I transgress.

Bowden's proposal that "academic commentators must show video of themselves at the killings or having beers with the killers" presumably refers to the second, more traumatic kind of encounter I describe here. ${ }^{5}$ However, sharing experiences (beers, lunch) with someone who has killed another human is surely less the point, than the relationship of the scholar to that person, to that violence. I do not believe that presence or trauma (be it primary or vicarious) are prerequisites for a researcher to speak about violence, but I do think that some sense of the visceral can be helpful in not falling into gratuitous sensationalism.

\section{Sensationalism}

6 Narco-culture has increasingly become a focus of academic study, and I have often felt outraged at the way in which victims and/or perpetrators of Mexico's bellicose violence are sensationalised, objectified and de-individualised by academics at 
conferences, with salacious accounts of dismembered women as "territories" in analyses of femicides, of spectacular deaths as "exchange commodities" in a system of narco accumulation. My argument is as much with analysts of literature and popular culture, as with music scholars. Violence in Mexico is notoriously spectacular, but there is no justification for its sensationalism to be furthered in academic accounts. Where is the humanity? I decry. The suffering, the agony of torture, rape, pre-death horror. The silenced bodies unearthed in fosas (mass graves), their skeletal mouths still screaming.

7 Sensationalism is distinguished from individual sensory knowledge by its relationality, specifically the relationship between a phenomenon and the sensed responses to it (be they emotional, intellectual, physical or otherwise), responses which are magnified in relation to measured rationality and so-called tastefulness. Back in 1992, in her analysis of mid-nineteenth century British sensation novels, Ann Cvetkovich argued that sensationalism:

produces the embodiment, in both the literal and figurative senses, of social structures. It not only renders them concrete, by embodying them in a single and powerful representation, but the responses it produces are bodily or physical experiences that seem immediate and natural. ${ }^{6}$

Moreover, Cvetkovich proposed, sensationalism can perform political work by making phenomena visible, often via spectacle. She evoked the ACT UP (AIDS Coalition to Unleash Power) movement of the 1980s (which emerged in the USA), where sensationalism was "endorsed as a useful tactic for goading people into an awareness of social problems". ' Cvetkovich poses the question: "what political possibilities are overlooked when sensationalism is condemned?" ${ }^{8}$ In the case of ACT UP, the stigma attached to the bodies of those subjected to state violence was politicised. Yet in necropolitical contexts such as twenty-first century Mexico, contesting state and criminal violence can be suicidal, and insensitivity to sadistic, spectacular violence is widespread, as Berlanga Gayón has explored, making it difficult to harness sensationalism as a tool for political ends, particularly since it is an important element of narco-propaganda. ${ }^{9}$ Thus, in response to the question of whether sensationalism can be justified in analyses of bellicose violence, I would argue that in necropolitical contexts, the answer is no.

\section{Answers, explanations and theories}

9 So if the use of sensationalism is inappropriate in necropolitical contexts, might there still be a place for answers and explanations, for the use theoretical material in analyses of brutal violence? It is not uncommon for researchers from the global north writing about necropolitical Mexico to justify their research with broad claims and even solutions to the drug-related, capitalism-fuelled violence in the country. I have been culprit to this, pointing to how the criminalisation of drugs sustains brutal violence and inequalities, and contesting the corruption and impunity which feeds this system. Yet I am a sociologist of music, an ethnomusicologist, without in-depth knowledge of broad socio-political issues. My primary hope is that my research on hip hop can do specific work: to reveal the mechanisms through which music and popular culture reproduce narco violence - by romanticising it, as well as critiquing it. ${ }^{10}$ While I disagree with Bowden's position that answers and explanations should be "killed", I also recognise that providing answers and explanations can do more work to make a 
scholar feel "good" about themselves and their discipline, than having an impact in the social world..$^{11}$ It is not uncommon for scholars to claim the uniqueness of their subject area in providing broad insights into human experience, for example that music provides understandings of violence that are particularly ground-breaking. I think we need to look ourselves hard in the mirror and reflect on whether we ask too much of our disciplines. Not enough people read academic texts to warrant a claim that research on hip hop is likely to stop violence in Mexico, but I do hope, maybe naively, that it could shift certain people's understanding.

In considering the appropriateness of using theoretical material in analyses of horrific violence, it is helpful to turn to work on film and photography where the glamorisation of horror has long been discussed. In her classic text Regarding the Pain of Others, Susan Sontag points to the tension between photographs as documentary and photographs as transforming their subjects into aesthetic objects. This tension is acute in war photography where critics consider suffering to be incompatible with beauty, and captions that moralise to be inappropriate. "In this view" Sontag argues,

a beautiful photograph drains attention from the sobering subject and turns it toward the medium itself, thereby compromising the picture's status as a document. The photograph gives mixed signals. Stop this, it urges. But it also exclaims, What a spectacle! ${ }^{12}$

11 War photography is a useful analogue for thinking about research material and theory in war-like contexts: like photography, scholarly analysis transforms and may be critiqued if overly theoretical about suffering subjects. Documentation may be considered more appropriate in depicting suffering, rather than a theoretical contribution to disciplinary and broader understandings. Likewise, analyses should not be moralising. Scholarly analysis of war zones, like war photography, (and it is apposite to quote Sontag again): "gives mixed signals. Stop this, it urges. But it also exclaims, What a spectacle!" 13 Where the spectacularisation of bellicose violence is combined with the fetishization of (usually French) theory, which is common in hegemonic, global northern musicology, humanities and social science, I contend that the ethics of global northern scholars using (colonial) theory in analyses of bellicose violence in the global south becomes ever more dubious. ${ }^{14}$

\section{Silence and humanity}

12 To conclude, let me clarify that I believe that silencing is counterproductive: there must always be space for a multiplicity of perspectives, for discussion and critique, in order to move ideas forward to enable collective action..$^{15}$ What is key in scholarship on bellicose violence is that people's humanity is maintained. Too often, victims and perpetrators are objectified. The ex-narco I interviewed told me that he often wondered who those people were, the ones he killed. He knew that they may not have worked for the other side, that they might have been innocent, but there was no going back after a certain point - they knew too much, or so he thought. That wondering who they were is not remorse, but it does bestow humanity. It is harder to sensationalise, to objectify others, when we are talking about individuals we have engaged with, people with a name, a life, a story. 


\section{BIBLIOGRAPHY}

BERLANGA GAYón Mariana, “El Espectáculo de la Violencia en el México Actual: Del Feminicidio al Juvenicidio", Athenea Digital, vol. 15, no. 4, 2015, pp. 105-128. DOI: https://doi.org/10.5565/rev/ athenea.1556

BORNSTEIN Erica, “Child Sponsorship, Evangelism, and Belonging in the Work of World Vision Zimbabwe”, American Ethnologist, vol. 28, no. 3, 2001, pp. 595-622. DOI: https://doi.org/10.1525/ae. 2001.28.3.595

BOWDEN Charles, Murder City: Ciudad Juárez and the Global Economy's New Killing Fields, New York City, Nation Books, 2010.

BURGoS DÁvILA César Jesús. “‘Que Truene la Tambora y Que Suene el Acordeón!’: Composición, Difusión y Consumo Juvenil de Narcocorridos en Sinaloa”, TRANS: Revista Transcultural de Música, Transcultural Music Review, vol. 20, 2016, pp. 1-24. https://www.sibetrans.com/trans/public/docs/ 01a-trans-2016.pdf

CAMPBELl Howard, “Narco-Propaganda in the Mexican 'Drug War': An Anthropological Perspective”, Latin American Perspectives, vol. 41, no. 2, 2014, pp. 60-77. DOI: https://doi.org/ 10.1177/0094582X12443519

CVETKOVICH Ann, Mixed Feelings: Feminism, Mass Culture, and Victorian Sensationalism, New Brunswick, Rutgers University Press, 1992.

DICKSON-SWIFT Virginia, JAMES Erica L., KIPPEN Sandra, LIAMPUTTONG Pranee, "Researching Sensitive Topics: Qualitative Research as Emotion Work”, Qualitative Research, vol. 9, no. 1, 2009, pp. 61-79. DOI: https://doi.org/10.1177/1468794108098031

DUBBERLEY Sam, GRANT Michele, “Journalism and Vicarious Trauma: A Guide for Journalists, Editors and News Organisations", 2017. Available at: https://firstdraftnews.org/wp-content/uploads/ 2017/04/vicarioustrauma.pdf, consulted on 05 January 2020).

EDBERG Mark, El Narcotraficante: Narcocorridos and the Construction of a Cultural Persona on the U.S. Mexico Border, Austin, University of Texas Press, 2004.

FISHER William F.,"Doing Good? The Politics and Antipolitics of NGO Practices”, Annual Review of Anthropology, vol. 26, no. 1, 1997, pp. 439-464. DOI: https://doi.org/10.1146/annurev.anthro. 26.1.439

MALCOMSON Hettie, “Aficionados, Academics, and Danzón Expertise: Exploring Hierarchies in Popular Music Knowledge Production”, Ethnomusicology, vol. 58, no. 2, 2014, pp. 222-253. DOI: https://doi.org/10.5406/ethnomusicology.58.2.0222

MALCOMSON Hettie, "Contesting Resistance, Protesting Violence: Women, War and Hip Hop in Mexico", Music and Arts in Action, vol. 7, no. 1, 2019a, pp. 46-63, http://musicandartsinaction.net/ index.php/maia/article/view/202/190

MALCOMSON Hettie, "Negotiating Violence and Creative Agency in Commissioned Mexican Narco Rap”, Bulletin of Latin American Research, vol. 38, no.3, 2019b, pp. 347-362. DOI: https://doi.org/ 10.1111/blar.12977

SIMONETT Helena, “Narcocorridos: An Emerging Micromusic of Nuevo L.A.", Ethnomusicology, vol. 45, no. 2, 2001, pp. 315-337. DOI: https://doi.org/10.2307/852677 
SIMONETT Helena, “Los Gallos Valientes: Examining Violence in Mexican Popular Music”, Trans, vol. 10, 2006, https://www.sibetrans.com/trans/articulo/149/los-gallos-valientes-examiningviolence-in-mexican-popular-music

SONTAG Susan, Regarding the Pain of Others, New York, Picador, 2003.

VALENZUELA ARCE José Manuel, Jefe de Jefes: Corridos y Narcocultura en México, México, Hoja Casa Editorial, 2003.

\section{NOTES}

1. BOWDEN Charles, Murder City: Ciudad Juárez and the Global Economy's New Killing Fields, New York, Nation Books, 2010, p. 209.

2. I use the term "narco" here as it is used widely in academia, but want to highlight that it is a stigmatising term which was rarely used by the rappers or ex-narco I interviewed: the terms "Them", malandros (badmen) and mafia were instead employed. The term narco rap, however, is a vernacular term.

3. See malcomson Hettie, "Negotiating Violence and Creative Agency in Commissioned Mexican Narco Rap", Bulletin of Latin American Research, vol.38, no. 3, 2019b, pp. 347-362. DOI: https:// doi.org/10.1111/blar.12977.

4. Analysis of, and advice regarding, traumatic fieldwork encounters and vicarious trauma is provided by DICKSON-SWIFT Virginia, JAMES Erica L., KIPPEN Sandra, LIAMPUTTONG Pranee, "Researching Sensitive Topics: Qualitative Research as Emotion Work", Qualitative Research, vol. 9, no. 1, 2009, pp. 61-79, DOI: https://doi.org/10.1177/1468794108098031; and DUBBERLEY Sam, GRANT Michele, "Journalism and Vicarious Trauma: A Guide for Journalists, Editors and News Organisations", 2017. Available at: https://firstdraftnews.org/wp-content/uploads/2017/04/ vicarioustrauma.pdf (consulted on 05 January 2020).

5. BOWDEN Charles, Murder City, p. 209.

6. сVеткоVich Ann, Mixed Feelings: Feminism, Mass Culture, and Victorian Sensationalism, New Brunswick, Rutgers University Press, 1992, p. 24.

7. Ibid., p. 24.

8. Ibid., p. 24.

9. Regarding indifference to violence in Mexico, see BERLANGA GAYÓN Mariana, "El Espectáculo de la Violencia en el México Actual: Del Feminicidio al Juvenicidio", Athenea Digital, vol. 15, no. 4, 2015, pp. 105-128. DOI: https://doi.org/10.5565/rev/athenea.1556. Regarding narco-propaganda, see for example, CAMPBell Howard, "Narco-Propaganda in the Mexican 'Drug War': An Anthropological Perspective", Latin American Perspectives, vol.41, no. 2, 2014, pp.60-77. DOI: https://doi.org/10.1177/0094582X12443519.

10. In conversation with important interventions on narcomusic and violence, such as: BURgos DÁvila César Jesús, “‘Que Truene la Tambora y Que Suene el Acordeón!’: Composición, Difusión y Consumo Juvenil de Narcocorridos en Sinaloa”, Trans, vol. 20, 2016, pp. 1-24, https:// www.sibetrans.com/trans/public/docs/01a-trans-2016.pdf; EDBERG Mark, El Narcotraficante: Narcocorridos and the Construction of a Cultural Persona on the U.S. Mexico Border, Austin, University of Texas Press, 2004; SIMONETT Helena, "Narcocorridos: An Emerging Micromusic of Nuevo L.A.", Ethnomusicology, vol. 45, no. 2, 2001, pp. 315-337. DOI: https://doi.org/10.2307/852677; SIMONETT Helena, "Los Gallos Valientes: Examining Violence in Mexican Popular Music", Trans, vol. 10, 2006, https://www.sibetrans.com/trans/articulo/149/los-gallos-valientes-examining-violencein-mexican-popular-music; VALENZUELA ARCE José Manuel, Jefe de Jefes: Corridos y Narcocultura en México, México, Hoja Casa Editorial, 2003. 
11. The notion and commodification of "goodness" was criticised (in relation to NGOs) some two decades ago by, amongst others, FISHER William F.,"Doing Good? The Politics and Antipolitics of NGO Practices", Annual Review of Anthropology, vol.26, no. 1, 1997, pp. 439-464. DOI: https:// doi.org/10.1146/annurev.anthro.26.1.439; and BORNSTEIN Erica, "Child Sponsorship, Evangelism, and Belonging in the Work of World Vision Zimbabwe", American Ethnologist, vol. 28, no. 3, 2001, pp. 595-622. DOI: https://doi.org/10.1525/ae.2001.28.3.595.

12. SONTAG Susan, Regarding the Pain of Others, New York, Picador, 2003, pp. 76-77.

13. Ibid., p. 77.

14. For an analysis of aficionado and hegemonic knowledge production in relation to danzón, see malcomson Hettie, "Aficionados, Academics, and Danzón Expertise: Exploring Hierarchies in Popular Music Knowledge Production", Ethnomusicology, vol.58, no. 2, 2014, pp. 222-253. DOI: https://doi.org/10.5406/ethnomusicology.58.2.0222.

15. I analyse distinct ways of critiquing bellicose violence in Mexico in MALCOMSON Hettie, "Contesting Resistance, Protesting Violence: Women, War and Hip Hop in Mexico", Music and Arts in Action, vol. 7, no. 1, 2019a, pp. 46-63, http://musicandartsinaction.net/index.php/maia/article/ view/202/190, where I focus on two rappers who were asked to address the theme of "war" in a rap battle: while both attempt to shift people's understandings and promote change, their strategies are distinct and are articulated in ways that go beyond universalist (white, liberal, masculinist, global northern) notions of resistance, I argue.

\section{ABSTRACTS}

This essay interrogates methodological, analytical and representational issues that continue to challenge scholars addressing bellicose violence: Is it ethical to write about terror, pain and despair from afar? Can sensationalism ever be justified in analyses of bellicose violence? What kind of silences might we allow for? These questions are explored in relation to necropolitical Mexico, drawing from empirical research with musicians commissioned to write narco rap, producers and consumers of rap del barrio, and hip hop artists protesting the disappearances, homicides, systematic violence and impunity enjoyed by criminal organisations and state institutions alike.

Cet article examine les enjeux de méthode, d'analyse et de représentation qui continuent de poser problème aux chercheur.e.s travaillant sur la violence de la guerre : est-ce éthiquement admissible d'écrire sur la terreur, la douleur et le désespoir depuis le confort de la distance ? Peut-on jamais justifier le sensationnalisme dans l'analyse de la violence guerrière ? Quels types de silence acceptera-t-on ? Ces questions sont explorées à travers la nécropolitique mexicaine, en s'appuyant sur des recherches empiriques auprès de musicien.ne.s chargé.e.s d'écrire du narco rap, de producteurs ou de consommateurs de rap del barrio, et d'artistes hip hop mobilisé.e.s contre les disparitions, les homicides, la violence systémique et l'impunité des organisations criminelles comme des institutions étatiques.

Este ensayo interroga cuestiones metodológicas, analíticas y de representación que continúan desafiando a lxs académicxs que abordan la violencia belicosa: ¿Es ético escribir sobre el terror, el dolor y la desesperación desde lejos? ¿Se puede justificar el sensacionalismo en los análisis de la violencia belicosa? ¿Qué clase de silencios podríamos permitir? Estas preguntas se exploran en 
relación con el México necropolítico a partir de una investigación empírica con músicos encargados de escribir narco rap, con productores y consumidores de rap del barrio, y con artistas de hip hop que protestan por las desapariciones, los homicidios, la violencia sistemática y la impunidad de la que gozan tanto las organizaciones criminales como las instituciones estatales.

\section{INDEX}

Mots-clés: sensationnalisme, violence, connaissance, trauma, éthique, hip hop, narco-culture, Mexique

Keywords: sensationalism, violence, knowledge, trauma, ethics, hip hop, narco-culture, Mexico Palabras claves: sensacionalismo, violencia, conocimiento, trauma, ética, hip hop, narcocultura, México

\section{AUTHOR}

\section{HETTIE MALCOMSON}

Hettie Malcomson is Associate Professor of Ethnomusicology at the University of Southampton. She trained in sociology, ethnomusicology and anthropology. Her work explores what the ethnographic study of music reveals about social inequalities. She has interrogated manifestations of racism, ageism and sexism through Mexican danzón; hierarchies of artistic and knowledge production through British new music; and, most recently, experiences of violence in Mexico through hip-hop. She received the honourable mention for the Society for Ethnomusicology's Bruno Nettl Prize. 